occupations. Pottery found in the old turf beneath the early rampart pointed to an occupation of an undefended village settlement dating at about 500 B.C. Then at about 250 B.c. the top of the hill was enclosed by a single rampart and ditch which are still visible as an inner work. At about 50 в.c. an extensive and ambitious scheme of refortification was undertaken, which included an outer rampart and ditch. This, however, seems not to have been completed. A complete rebuilding took place in the year, approximately, A.D. 50, when a full outer rampart and ditch were constructed. The site was then neglected for a thousand years, until in the eleventh century some refortification took place. The excavations have been carried out by Dr. Wilson on behalf of the Brighton and Hove Archæological Society, with the assistance of Dr. Cecil Curwen and Mr. G. P. Burstow.

An account with photographs of the recently discovered western postern for pedestrians of the
Newport Arch at Lincoln is given by Mr. F. T. Baker in Discovery of February. This arch, famous for having been in uninterrupted use since its erection probably in the second century A.D., was the northern gateway of the Roman occupation. The surviving portion consists of the southern face of the main arch and an eastern postern; but the demolition last autumn of a building abutting on the western side of the arch brought to light the spring of an arch, which confirmed previous conjecture that there had also been a postern for pedestrians on the western side. It is evident that barrack rooms, or chambers for some such purpose surmounted the arch. The discovery of a portion of the Roman city wall in the course of the work indicates that this met the structure of the gate at approximately the centre, and not flush with the south or north face as previously thought. The exterior angle, possibly, may have been filled by a bastion.

\title{
The Rockefeller Foundation*
}

\section{Barriers to International Aims}

$\mathrm{F}^{\mathrm{H}}$ ROM the beginning of its activities twenty-five years ago the Rockefeller Foundation has been guided by the objective written into its charter : "The wellbeing of mankind throughout the world". In accordance with this purpose the aim of the trustees has been to maintain the work of the Foundation on an international plane without consideration of flags or political doctrines or creeds or sects. Particularly in a programme based on the advancement of knowledge it is imperative to disregard the geographical boundaries which arbitrarily and often unhappily divide the earth into a patchwork of senseless antagonisms. For in the last analysis knowledge cannot be nationalized. No successful embargoes can be maintained against the export or import of ideas. Whether new conceptions in atomic physics come from Copenhagen or from Cambridge, England; whether the cure for cancer is developed in New Haven or in Berlin; whether it is a Russian or an Italian or an American who takes the next step forward in mankind's struggle with virus diseases-we are all of us, under whatever flag, the joint beneficiaries of the intellectual property of the race. In all the clash of competing nationalisms there is here an underlying principle of unity : the single aim and language of science in the discovery of truth. It is this principle which challenges the twentieth century with the conception of civilization as a co-operative achievement and with the ideal of intellectual capital as an international possession.

A foundation, therefore, whose aim is to assist in pushing out the boundaries of knowledge must necessarily work wherever the best tools are to be found. In its search for high talent and promising opportunities it must assume that frontiers are not the forbidding barriers they pretend to be.

This ideal, which for more than two decades the Rockefeller Foundation has consistently attempted to follow, has in recent years encountered serious difficulties. And these difficulties are increasing. Objective scholarship is possible only where thought

* From the Rockefeller Foundation: A Review for 1937. By Raymond B. Fosdick, President of the Foundation. (New York, 1938.) is free-and freedom can exist only where there is tolerance, only where there are no "Keep Out" signs against the inquisitive and questioning mind. Disinterested research cannot survive in an atmosphere of compulsion and repression. It withers under the efforts of Governments to impose uniform ideologies and to circumscribe in the interests of a dominant regime the area of intellectual liberty. Particularly in the broad range of subjects covered by the social sciences, and in the humanities as well, the world has recently witnessed in several countries the progressive disintegration of creative scholarship.

This phenomenon has naturally affected the programme of the Foundation. In some fields it is now profitless to go where we formerly went. We find ourselves stopped at some frontiers- not because the frontiers have any greater geographical significance than they had a few years ago, but because behind them the search for truth by eager and sceptical minds has been made impossible.

Some twenty years ago in a Central American city a revolution developed while the Foundation was engaged in a study of yellow fever control measures. Dr. Emmett Vaughn, who was in charge of the work, determined to continue his research. Every morning with a flag of truce he crawled through the barricades to collect his mosquitos on one side of the fighting line, and in the aftermoon he crawled back again to gather up his specimens on the other side. He was molested by neither army. Both sides thought him somewhat crazy - a man who, when great issues of human destiny were being fought out, spent his time catching mosquitos. To-day in that Central American country the revolution has been largely forgotten, but Dr. Vaughn is remembered as the man who helped to stamp out an age-long pestilence.

The Rockefeller Foundations likes to think of this incident as an example of what its approach to the welfare of mankind should be. But occasionally aggressive action by the fighting lines makes impossible even the gathering of mosquitos ! 